COVIRO-D-16-00047 Revision

\title{
Systemic delivery of adeno-associated viral vectors
}

Dongsheng Duan, Ph.D.

Department of Molecular Microbiology and Immunology, School of Medicine, The University of Missouri, Columbia, MO 65212, USA

Department of Neurology, School of Medicine, The University of Missouri, Columbia, MO 65212, USA

Department of Bioengineering, The University of Missouri, Columbia, MO 65212, USA Department of Biomedical Sciences, College of Veterinary Medicine, The University of Missouri, Columbia, MO 65212, USA

Corresponding Address: Dongsheng Duan Ph.D.

Professor

Department of Molecular Microbiology and Immunology

One Hospital Dr.

Columbia, MO 65212

Phone: 573-884-9584

Fax: 573-882-4287

Email: duand@missouri.edu

Running title: Systemic AAV delivery

Abstract: 120

Total words: 2,489

Figures: 2

Tables: 1 


\begin{abstract}
For diseases like muscular dystrophy, aneffective gene therapy requiresbodywide correction. Systemic viral vector delivery has been attempted since early 90s. Yet a true success was not achieved until mid-2000 when adeno-associated virus (AAV) serotype-6, 8 and 9 were found to result in global muscle transduction in rodents following intravenous injection. The simplicity of the technique immediately attracts attention. Marvelous whole body amelioration has been achieved in rodent models of many diseases. Scale-up in large mammals also shows promising results. Importantly, the first systemic AAV-9 therapy was initiated in patients in April 2014. Recent studies have now begun to reveal molecular underpinnings of systemic AAV delivery and to engineer new AAV capsids with superior propertiesfor systemic gene therapy.
\end{abstract}

\title{
Highlights
}

Only intravascular delivery can truly change the course of systemic diseases AAV has the capacity to escape from the blood and lead to bodywide gene transfer Systemic AAV therapy has been achieved in rodents and large mammals Molecular engineering can lead to new AAV capsids for enhanced systemic delivery 


\section{Introduction}

Many life-threatening diseases affect a number of organs or affect tissues that are widely distributed. A successful gene therapy for these diseases requires a viral vector that can effectively reach all target cells throughout the body. Since our vessels are a built-in and ready-to-use system for bodywide transportation, a convenient strategy to achieve systemic delivery would be infusion of a therapeutic viral vector into the circulation. For this seeming straightforward method to work, a viral vector has to reach the target area, get out from the vasculature and infect the diseased cells.

A report in 1992 claimed to have achieved "widespread long-term gene transfer" to striated muscles in newborn mice using recombinant adenovirus [1]. The authors delivered adenovirus intravenously to 2 to 5 -day-old mice and detected some expression in the liver, lung, heart and skeletal muscle. While the adenoviral vector had indeed spread to various tissues and organs, there were only sporadic transduction in skeletal muscle and $\sim 0.2 \%$ transduction in the heart. This is far from 20 to $50 \%$ gene transfer efficiency required to treat skeletal muscle disease and cardiomyopathy in diseases like Duchenne muscular dystrophy (DMD)[2,3]. Several strategies were developedto overcome the endothelial barrier for systemic adenovirus delivery. These include the application of vessel dilator and permeabilizer, hydrodynamic injection and viral capsid modification [4-6].Despite improved intravascular transduction of a single limb with pressurized infusion and endothelial permeabilization, adenoviral vectors eventually losethe favor for systemic delivery due to severe immune responses and fatal complications [7].

Over the last two decades, adeno-associated virus (AAV) has emerged and now become the most preferred vector for gene therapy [8-11]. AAV is a single stranded DNA virus discovered in 1965 [12]. It persists mainly as episomal molecules in infected tissues [13-15]. More than 12 different serotypes and hundreds of capsid variants have been isolated from adenoviral stocks and animal tissues or engineered in laboratories. In contrast to adenovirus, intramuscular injection of recombinant AAV serotype-2 (AAV2) resulted in yearlongrobust transduction with nominal cellular immune responses $[16,17]$. Strategies that have been shown to enhance adenoviral intravascular delivery 
(such as pharmacological vessel permeabilization and forced extravasation) also resulted in uniform whole limb muscle transduction by AAV-2[4,18]. However, there remains a significant gap to achieve whole body gene transfer from peripheral vessels. A bona fide breakthrough in systemic gene deliveryhas to wait until new AAV serotypes are isolated.

\section{Systemic gene delivery with AAV in rodents}

In early days of AAV vector development, most studies are focused on AAV-2. Isolation of new serotypes has greatlyexpandedthe repertoire [19-21]. Rutledge et al isolated AAV-6 from an adenovirus stock [22]. Gao et al isolated AAV-8 and AAV-9 from tissues of rhesus monkey and human, respectively $[23,24]$. These three serotypes open the door to a successful systemic delivery. Gregorevic et al showed efficient whole body striated muscle transduction in mice after tail vein injection of AAV- 6 and the vascular endothelium growth factor for transient microvasculature permeabilization [25]. Wang et al achieved widespread saturated transduction of the heart as well as axial and appendicular muscles in mice and hamsters via systemic delivery of AAV-8[26]. Shortly after, successful bodywide systemic gene transfer was established for AAV-9(Figure 1) [27-29]. Interestingly, peripheral delivery of AAV-9 resulted in superior myocardial and central nervous system transduction. It is now clear that other AAV serotypes (such as AAV-1 and AAV-7) can also lead to systemic transduction (Table 1) [26,30,31]. Nevertheless, AAV-9 remains the most potent serotype for systemic delivery in rodents [30-32].

The establishment of systemic AAV delivery technique immediately raises the possibility for bodywide correction in rodent models of humandiseases. Today, impressive results have been reported in neonatal, adult and even aged animals. Some of these examples include AAV-1 mediated gene therapy for Pompe disease,limb-girdle muscular dystrophy (LGMD) and myotonic dystrophy[33-35], AAV-6 mediated gene therapy for DMD and facioscapulohumeral muscular dystrophy[25,36-38], AAV-8mediated gene therapy for DMD,LGMD and atherosclerosis[26,39-41], andAAV-9 mediated gene therapy for cardiomyopathy,lysosomal storage disordersand neuronal diseases [42-51]. 
The maximal packaging capacity of an AAV vector is $\sim 5-\mathrm{kb}$ [52-55]. This limits the use of AAV for a number of diseases including DMD and dysferlin-deficient myopathy. Various dual AAV strategies have been developed to overcome this hurdle (reviewed in [56-58]). Optimized dual AAV vectors have reach transduction efficiency of the single AAV vector $[59,60]$. Ghosh et al provided the first proof-of-principleevidence for efficient systemic dual AAV delivery in normal and diseased mice [61,62]. Subsequent studies from several laboratories showed unequivocal evidence that systemic dual AAV therapy is a viable option for bodywide alleviation for DMD and dysferlin-deficient myopathy [63-65].

\section{Scale-up systemic AAV delivery in large mammals}

The remarkable success in rodents and the convenience of the technique have stimulated tremendous interests in adopting systemic AAV delivery to large mammals. The first successful systemic AAV delivery to a large mammal was achieved with AAV-9 in newborn canines (Figure 1)[66]. Surprisingly, despite spectacular bodywide skeletal muscle transduction, few cardiomyocytes were transduced [66]. In sharp contrast, AAV-8 yielded robust transduction of both skeletal and cardiac muscles in dog puppies

(Figure 1)[67,68]. AAV-1 and AAV-6 are two other serotypes that have shown good systemic transduction in rodents $[26,30,31]$. Recent studies suggest that mutating surface-exposed tyrosine can significantly enhance AAV transduction $[69,70]$. Hakim et al tested tyrosine modified AAV-1 and AAV-6 in neonatal dogs [71]. Interestingly, AAV1 showed high efficient whole body striated muscle transduction but AAV- 6 resulted in little muscle transduction (Figure 1). Two groups explored systemic AAV-9 delivery in newborn DMD puppies [72,73]. Gene transfer was observed in multiple muscles up to 4 months of age. However, Kornegay et al encountered a catastrophic inflammatory response potentially linked to the transgene product [73]. Contrary to Kornegay et al, Hinderer et al reasoned that neonatal period could be a window to induce immune tolerance to the transgene product [74]. Indeed, they were able to achieve this goal by systemic delivery of low-dose AAV-8 (30-fold lower than used by Kornegay et al) in rhesus monkeys and type I mucopolysaccharidosis dogs [74]. 
Very few studies have evaluated systemic AAV delivery to adult large mammals. An early work in cynomologus monkeys suggests that even very low-dose AAV $(\leq 5 \mathrm{x}$ $10^{10}$ particles $/ \mathrm{kg}$ ) can result in vector genome accumulation in the spleen and expression in the lympho nodes [75]. Intriguingly, regional intravascular delivery of AAV to nonhuman primates is devoid of cellular immunotoxicity [76-78]. Several groups have shown successful regional limb perfusion with AAV-1 and 8 in normal and diseased dogs [79-82]. Abreakthrough of systemic AAV transfer in a diseased adult large mammal has not been achieved until recently. Yue et alinjected tyrosine mutant AAV-9 to young adult DMD dogs from a peripheral vein and observed efficient global skeletal and cardiac muscle transduction without serious complications (Figure 1)[83]. Hakim et al further extended this result demonstrating systemic delivery of an AAV-9 microdystrophin vector can lead to near saturated expression for at least 12 months without any toxicity in adult affected dogs [84].

The most exciting progress is the ongoing clinical trial in neonatal spinal muscular atrophy (SMA) patients using AAV-9 by Drs. Mendel, Kaspar and colleagues (clinical trial ID: NCT02122952)[85]. SMA is caused by mutations in the survival motor neuron 1 (SMN1) gene. Earlier studies from several groups have revealed remarkable therapeutic benefits in newborn SMA micewith AAV-9 mediated systemic SMN1 gene therapy [86-89]. In this game-changing clinical trial, fifteen 1 to 8-m-old patients received intravenous injection of up to $2 \times 10^{14}$ particles $/ \mathrm{kg}$ of the AAV-9 SMN1 vector. Some patients have been treated for almost two years. There was no major safety concerns. Importantly, high-dose group patients showed clinical improvement[85].

\section{Mechanistic insights of systemic AAV delivery}

A better understanding on the mechanisms of systemic AAV transduction is essential to further improve this important gene therapy technology. The major ratelimiting steps may include interaction with serum proteins, blood clearance, vessel escape, attachment,endocytosis, intracellular processing,nuclear entry and vector genome conversion (Figure 2, Table 1). The last five steps have been extensively reviewed elsewhere and will not be discussed here $[90,91]$. 
Interaction of AAV with circulating proteins greatly influences the outcome of systemic delivery. Inactivation by pre-existing neutralizing antibodies has been well documented. Recently, Denard et al found that some blood proteins bind to certain AAV serotypes in a species-specific manner [92,93]. In particular, AAV-6 interacts with the galectin 3 binding protein in human and dog sera but not macaque and mouse sera. This interaction aggregates AAV particles and hampers systemic delivery [92]. On the other side, AAV-6 interacts with the C-reactive protein in mouse but not human sera. Instead of inhibition, this interaction boosts systemic delivery [93].

Blood clearance varies dramatically among AAV serotypes [31,94]. While rapid clearance may not necessarily abort systemic delivery, prolongation of the circulation time certainly enhances it [31,94-96]. In this regard, delayed clearance has been suggested as a primary reason underlying pronounced systemic delivery of AAV-9 [94]. Shen et al investigated the underlying mechanisms for extended persistence of AAV-9 in blood and found that it is due to the low abundance of the AAV-9 receptor, hencereduced tissue binding[95]. It is very likely that the blood clearance of AAV is regulated by many factors. Additional studies may reveal these yet unknown factors. On the other side, future studies are also needed to explain why fast blood clearance of some AAV serotypes (such as AAV-8) has minimal impact on systemic delivery (Table 1).

Depending on the architecture of capillary, AAV may get out from blood via two different pathways, paracellular or transcellular (Figure 2). Paracellular transport refers to the escape of virus from the circulation through the space between adjacent endothelial cells. Capillaries in the liver and spleen are fenestrated and discontinuous (Figure 2). In these tissues, AAV can readily diffuse out through large gaps between endothelial cells. This paracellular mechanism contributes to the accumulation of the AAV genome in the liver following systemic delivery $[25,27,30,31,83,97]$.

In the central nerve system, the tight junctions between neighboring endothelial cells form the highly selective blood-brain barrier (Figure 2). In this case, the only way to escape from the circulation is transcellular transcytosis(Figure 2). In this process, AAV is taken into endothelial cells in specialized vesicles[98]. These vesicles traffic to the other side of the cell and release virus into the interstitium. AAV transcytosis has 
been documented in vitro[99-101]. Interestingly, AAV-8 and 9 show efficient transcytosis but AAV-6 dose not [100-102]. Recent studies have revealed two distinctive mechanisms of transcytosis, dependent or independent of caveolae [103]. Kotchey et al found that systemic AAV-9transduction is not compromised in cavelin-1 knockout mice. Since AAV-9 displays unparalleled superior neuronal tissue transduction when delivered through the peripheral vein [104], it is very likely that transvascular transport of AAV-9 is through caveolae-independent transcytosis [94].

\section{Re-engineering AAV for improved systemic delivery}

Despite the great promise of systemic delivery, the current technology remains limited. For example, a large proportion of humans are seropositive for known AAV serotypes $[105,106]$. Further, systemic delivery often leads to gene transfer in nontarget tissues and organs. AAV transduction is largely determined by the viral capsid, especially variable loops on the surface[107-109]. Several strategies have been used to develop novel capsidsfor improved systemic delivery. These include (1) isolation and reconstruction from existing or ancestral species[110,111], and (2) modification by rational design and directed evolution[112,113].

Many new AAV isolates have been tested for systemic delivery recently. These studies have revealed some unique organism, organ, tissue, or cell-type specific transduction pattern after intravascular delivery. For example, AAV-3B showed superior hepatotropism in primate but not rodent liver [114-116]. AAV-4 showed selective cardiopulmonary tropism [117]. AAV-rh8 and rh10 are as efficient as AAV-9 in crossing the blood-brain barrier [118].

A hurdle to systemic AAV delivery is the high prevalence (40-80\%) of pre-existing immunity in human populations (reviewed in [119]). While some successes have been achieved with the application of immune suppressive drugs (such as anti-CD20 antibody rituximab) and plasmapheresis [120-122], modification of the antigenic epitope on the capsid may yield neutralizing-resistant "designer" AAV variants. Several approaches have been used to map the neutralizing antibody binding epitopes for different AAV serotypes (reviewed in [123]). These studies suggest that protrusions around the 3-fold axis and 2/5-fold wall participate in interactions with neutralizing 
antibodies [123]. Targeted mutagenesis of these residues may circumvent preexisting immunity[124,125]. An alternative and highly effective method to known epitope mutagenesis is forced evolution in the presence of high amounts of neutralizing antibodies (such as pooled immunoglobulins from human donors) (reviewed in $[112,126])$. This approach has allowed isolation of neutralizing antibody escaping AAV variantsAAV-r2.15by Maheshri et al and AAV-DJ by Grimm et al $[127,128]$. More recently, Li et al found that capsid variants isolated following in vitro selection in human serum had poor in vivo transduction strength although they were able to escape neutralization[129]. In vivo selection in the presence of the patient serum may yield escaping-capsids with better in vivo performance[129].

Blood clearance is a rate-limiting barrier in systemic delivery. The determinants for AAV-9 blood clearance were reported recently $[94,95,130]$. These mainly consist of surface-exposed amino acids and overlap with the receptor footprint. Mutations in these residues substantially shorten circulation half-life and reduce systemic transduction[94,95,130].

Delivery of a viral vector through the bloodstream will likely spread the virus to untoward tissues/organs. This raises safety concerns. Sequestration of AAV in these non-target locations also reduces the amount of vectors that can be delivered to the targets and hence has significant implications on the effective vector dose needed for systemic therapy. Tissue/cell-specific AAV will help resolve this problem. A series of tropism-modified AAV capsid variants have been developed using either in vivo evolution or educated engineering. These capsid chimeras are highly desirable for systemic gene therapy of various diseases, for example, liver-detargeted vectors for muscular dystrophy [96,130-132], liver-enhanced vectors for hemophilia [128,133], myocardium tropic vectors for cardiomyopathy [134], central nerve system-enhanced vectors for neurodegenerative diseases[135].

AAV uses cell surface carbohydrates as its binding receptors [136]. The nature and abundance of these extracellular glycans vary dramatically between different species and at different developmental stages. Since AAV attachment is a determining factor in systemic delivery, cautions should be taken to extrapolate re-engineered capsids for different applications [102,115,116,137]. 


\section{Conclusion}

The non-invasive nature and the convenience of peripheralvascular deliverypromise a straightforward approach to treating a number of diseases. Many barriers have been overcome. However, there remain significant hurdles to translate the promise of systemic delivery into clinical benefits in human patients. Further, new challenges will surfaceas we learn more about AAV (such as the discovery of the universal AAV receptor) and begin to apply systemic delivery to new technologies (such as gene editing with the CRISPR technology) $[138,139]$. The study on systemic viral vector delivery has just reached its prime time and the best is yet to come. 
Tables

Table 1. Comparison of AAV-2 with AAV-1, 6, 7, 8 and 9 for systemic delivery 


\section{Figure legends}

Figure 1. Systemic AAV delivery results in bodywide gene transfer in rodents and large mammals. Peripheral vascular delivery provides a method that allows an AAV

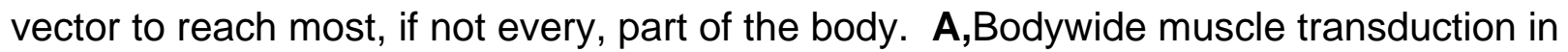
mice following tail vein delivery of an alkaline phosphatase (AP) reporter gene AAV-9 vector. B,Robust and persistent (up to one year) skeletal muscle and myocardial transduction after jugular vein injection of an AAV-8 AP vector in a neonatal dog. C, Tyrosine mutant AAV-9 results in whole body striated muscle transduction in young adult dystrophic dogs. Top panel, representative full-view images from selected skeletal muscles; middle panel, representative high-power images from selected skeletal muscles, heart and internal organs; bottom panel, quantification of the AAV genome and AP expression in selective tissues. BB, biceps brachii; Bra, brachialis; Dia, diaphragm; CT, cranial tibialis; ECR, extensor carpi radialis; FCU, flexor carpi ulnaris; FD, flexor digitorum; Gas, gastrocnemius; IS, interstitial septum; LV, left ventricle; LVa, left ventricle anterior portion; LVx, left ventricle apex; PM, papillary muscle; Sep, septum; TB, triceps brachii; Ter, teres; Ton, tongue; VM, vastus medialis.

Figure 2. Rate-limiting steps in systemic AAV delivery. The major rate-limiting steps include interaction with serum proteins (such as neutralizing antibodies), blood clearance, vessel escape, attachment, endocytosis, intracellular processing, nuclear entry and vector genome conversion. Capsid engineering can yield new AAV variants with enhanced systemic delivery properties. Numerical numbers highlight five ratelimiting barriers. Capillaries in the central nerve system (CNS) are sealed by the bloodbrain barrier. Transcytosis is the only way for AAV to exit the vasculature in CNS. Capillaries in the liver and spleen are fenestrated and discontinuous. This allows for efficient paracellular diffusion of AAV into the parenchyma. Capillaries in muscles may allow for limited paracellular transport of AAV. However, transcytosis may likely be the primary pathway for AAV to get to muscle. 


\section{Acknowledgement}

The research in the Duan lab is supported by the National Institutes of Health (NS-90634, AR-69085, AR-67985 and AR-70517), Department of Defense (MD130014 and MD150133), Muscular Dystrophy Association, Jesse's Journey-The Foundation for Gene and Cell Therapy, Parent Project Muscular Dystrophy, Hope for Javier, Solid GT LLC and the University of Missouri.

\section{Disclosure}

D.D. is a member of the scientific advisory board for Solid GT, LLC and an equity holder of Solid GT, LLC. The Duan lab has received research supports from Solid GT, LLC. 


\section{References}

1. Stratford-Perricaudet LD, Makeh I, Perricaudet M, Briand P: Widespread long-term gene transfer to mouse skeletal muscles and heart. J Clin Invest 1992, 90:626-630.

2. Chamberlain JS: Gene therapy of muscular dystrophy. Hum Mol Genet 2002, 11:2355-2362.

3. Duan D: Challenges and opportunities in dystrophin-deficient cardiomyopathy gene therapy. Hum Mol Genet 2006, 15 Spec No 2:R253-261.

4. Greelish JP, Su LT, Lankford EB, Burkman JM, Chen H, Konig SK, Mercier IM, Desjardins PR, Mitchell MA, Zheng XG, et al.: Stable restoration of the sarcoglycan complex in dystrophic muscle perfused with histamine and a recombinant adeno-associated viral vector. Nat Med 1999, 5:439-443.

5. Douglas JT, Curiel DT: Strategies to accomplish targeted gene delivery to muscle cells employing tropism-modified adenoviral vectors. Neuromuscul Disord 1997, 7:284-298.

6. Cho WK, Ebihara S, Nalbantoglu J, Gilbert R, Massie B, Holland P, Karpati G, Petrof $\mathrm{BJ}$ : Modulation of Starling forces and muscle fiber maturity permits adenovirus-mediated gene transfer to adult dystrophic (mdx) mice by the intravascular route Hum Gene Ther 2000, 11:701-714.

7. Wilson JM: Lessons learned from the gene therapy trial for ornithine transcarbamylase deficiency. Mol Genet Metab 2009, 96:151-157.

*8. Muzyczka N: Use of adeno-associated virus as a general transduction vector for mammalian cells. Curr Top Microbiol Immunol 1992, 158:97-129.

*This review article summarizes the very early stage of AAV vector development.

*9. Carter BJ: Adeno-associated virus and the development of adeno-associated virus vectors: a historical perspective. Mol Ther 2004, 10:981-989.

${ }^{*}$ This is a comprehensive review of the history of AAV vector development.

*10. Samulski RJ, Muzyczka N: AAV-mediated gene therapy for research and therapeutic purposes. Annu Rev Virol 2014, 1:427-451.

*This is a comprehensive review of AAV transduction biology.

11. Muzyczka N, Berns KI: AAV's golden jubilee. Mol Ther 2015, 23:807-808.

12. Atchison RW, Casto BC, Hammon WM: Adenovirus-associated defective virus particles. Science 1965, 149:754-756.

13. Duan D, Sharma P, Yang J, Yue Y, Dudus L, Zhang Y, Fisher KJ, Engelhardt JF: Circular intermediates of recombinant adeno-associated virus have defined structural characteristics responsible for long term episomal persistence In muscle. J. Virol. 1998, 72:8568-8577.

14. Schnepp BC, Jensen RL, Chen CL, Johnson PR, Clark KR: Characterization of adeno-associated virus genomes isolated from human tissues. $J$ Virol 2005, 79:14793-14803. 
15. Penaud-Budloo M, Le Guiner C, Nowrouzi A, Toromanoff A, Cherel Y, Chenuaud P, Schmidt M, von Kalle C, Rolling F, Moullier $\mathrm{P}$, et al.: Adeno-associated virus vector genomes persist as episomal chromatin in primate muscle. J Virol 2008, 82:7875-7885.

16. Xiao X, Li J, Samulski RJ: Efficient long-term gene transfer into muscle tissue of immunocompetent mice by adeno-associated virus vector. J Virol 1996, 70:8098-8108.

17. Kessler PD, Podsakoff GM, Chen X, McQuiston SA, Colosi PC, Matelis LA, Kurtzman GJ, Byrne BJ: Gene delivery to skeletal muscle results in sustained expression and systemic delivery of a therapeutic protein. Proc Natl Acad Sci U S A 1996, 93:14082-14087.

18. Su LT, Gopal K, Wang Z, Yin X, Nelson A, Kozyak BW, Burkman JM, Mitchell MA, Low DW, Bridges CR, et al.: Uniform scale-independent gene transfer to striated muscle after transvenular extravasation of vector. Circulation 2005, 112:1780-1788.

19. Wu Z, Asokan A, Samulski RJ: Adeno-associated virus serotypes: vector toolkit for human gene therapy. Mol Ther 2006, 14:316-327.

20. Gao G, Vandenberghe LH, Wilson JM: New recombinant serotypes of AAV vectors. Curr Gene Ther 2005, 5:285-297.

21. Vandenberghe LH, Wilson JM, Gao G: Tailoring the AAV vector capsid for gene therapy. Gene Ther 2009, 16:311-319.

22. Rutledge EA, Halbert CL, Russell DW: Infectious clones and vectors derived from adeno-associated virus (AAV) serotypes other than AAV type 2. J Virol 1998, 72:309-319.

**23. Gao GP, Alvira MR, Wang L, Calcedo R, Johnston J, Wilson JM: Novel adenoassociated viruses from rhesus monkeys as vectors for human gene therapy. Proc Natl Acad Sci U S A 2002, 99:11854-11859.

**This study opens the door of isolating new AAV variants from mammalian tissues. Several AAV serotypes discovered in this study (such as AAV-8 and AAV-9) show excellent systemic delivery property and are currently in human trials.

24. Gao G, Vandenberghe LH, Alvira MR, Lu Y, Calcedo R, Zhou X, Wilson JM: Clades of adeno-associated viruses are widely disseminated in human tissues. $J$ Virol 2004, 78:6381-6388.

**25. Gregorevic P, Blankinship MJ, Allen JM, Crawford RW, Meuse L, Miller DG, Russell DW, Chamberlain JS: Systemic delivery of genes to striated muscles using adeno-associated viral vectors. Nat Med 2004, 10:828-834.

${ }^{\star *}$ This is the first report of successful systemic AAV delivery in mice. The authors utilized AAV-6. In order to achieve high efficient bodywide delivery, the authors co-administrated VEGF, a transient vessel permeabilizer.

**26. Wang Z, Zhu T, Qiao C, Zhou L, Wang B, Zhang J, Chen C, Li J, Xiao X: Adenoassociated virus serotype 8 efficiently delivers genes to muscle and heart. Nat Biotechnol 2005, 23:321-328.

**This is the first report demonstrating whole body systemic delivery of an AAV vector in rodents in the absence of pharmacological vessel permeibilization. 
*27. Inagaki K, Fuess S, Storm TA, Gibson GA, McTiernan CF, Kay MA, Nakai H: Robust systemic transduction with AAV9 vectors in mice: efficient global cardiac gene transfer superior to that of AAV8. Mol Ther 2006, 14:45-53.

*References \#27 to 28 show robust myocardial transduction of AAV-9 suggesting AAV9 is cardiotropic in rodent heart.

*28. Pacak CA, Mah CS, Thattaliyath BD, Conlon TJ, Lewis MA, Cloutier DE, Zolotukhin I, Tarantal AF, Byrne BJ: Recombinant adeno-associated virus serotype 9 leads to preferential cardiac transduction in vivo. Circ Res 2006, 99:e3-9.

*References \#27 to 28 show robust myocardial transduction of AAV-9 suggesting AAV9 is cardiotropic in rodent heart.

*29. Bostick B, Ghosh A, Yue Y, Long C, Duan D: Systemic AAV-9 transduction in mice is influenced by animal age but not by the route of administration. Gene Ther 2007, 14:1605-1609.

*References \#27 to 28 show robust myocardial transduction of AAV-9 suggesting AAV9 is cardiotropic in rodent heart.

30. Bish LT, Morine K, Sleeper MM, Sanmiguel J, Wu D, Gao G, Wilson JM, Sweeney $\mathrm{HL}$ : Adeno-associated virus (AAV) serotype 9 provides global cardiac gene transfer superior to AAV1, AAV6, AAV7, and AAV8 in the mouse and rat. Hum Gene Ther 2008, 19:1359-1368.

*31. Zincarelli C, Soltys S, Rengo G, Rabinowitz JE: Analysis of AAV serotypes 1-9 mediated gene expression and tropism in mice after systemic injection. $\mathrm{Mol}$ Ther 2008, 16:1073-1080.

*This study reports side-by-side comparison of systemic delivery efficiency of AAV-1 to AAV-9. This study suggests that AAV-9 is suprior to other serotypes.

32. Prasad KM, Xu Y, Yang Z, Acton ST, French BA: Robust cardiomyocyte-specific gene expression following systemic injection of AAV: in vivo gene delivery follows a Poisson distribution. Gene Ther 2011, 18:43-52.

33. Bisset DR, Stepniak-Konieczna EA, Zavaljevski M, Wei J, Carter GT, Weiss MD, Chamberlain JR: Therapeutic impact of systemic AAV-mediated RNA interference in a mouse model of myotonic dystrophy. Hum Mol Genet 2015, 24:4971-4983.

34. Mah C, Pacak CA, Cresawn KO, Deruisseau LR, Germain S, Lewis MA, Cloutier DA, Fuller DD, Byrne BJ: Physiological correction of Pompe disease by systemic delivery of adeno-associated virus serotype 1 vectors. Mol Ther 2007, 15:501-507.

35. Fougerousse F, Bartoli M, Poupiot J, Arandel L, Durand M, Guerchet N, Gicquel E, Danos O, Richard I: Phenotypic correction of alpha-sarcoglycan deficiency by intra-arterial injection of a muscle-specific serotype 1 rAAV vector. Mol Ther 2007, 15:53-61.

*36. Gregorevic P, Allen JM, Minami E, Blankinship MJ, Haraguchi M, Meuse L, Finn E, Adams ME, Froehner SC, Murry CE, et al.: rAAV6-microdystrophin preserves 
muscle function and extends lifespan in severely dystrophic mice. Nat Med 2006, 12:787-789.

*This study shows systemic AAV-6 therapy ameliroated dystrophic phenotype in dystrophin/utrophin double knockout mice.

37. Gregorevic P, Blankinship MJ, Allen JM, Chamberlain JS: Systemic microdystrophin gene delivery improves skeletal muscle structure and function in old dystrophic mdx mice. Mol Ther 2008, 16:657-664.

38. Bortolanza S, Nonis A, Sanvito F, Maciotta S, Sitia G, Wei J, Torrente Y, Di Serio C, Chamberlain JR, Gabellini D: AAV6-mediated systemic shRNA delivery reverses disease in a mouse model of facioscapulohumeral muscular dystrophy. Mol Ther 2011, 19:2055-2064.

39. Nishiyama A, Ampong BN, Ohshima S, Shin JH, Nakai H, Imamura M, MiyagoeSuzuki Y, Okada T, Takeda S: Recombinant adeno-associated virus type 8mediated extensive therapeutic gene delivery into skeletal muscle of alphasarcoglycan-deficient mice. Hum Gene Ther 2008, 19:719-730.

40. Qiao C, Li J, Jiang J, Zhu X, Wang B, Xiao X: Myostatin propeptide gene delivery by adeno-associated virus serotype 8 vectors enhances muscle growth and ameliorates dystrophic phenotypes in mdx mice. Hum Gene Ther 2008, 19:241-254.

41. Khan JA, Cao M, Kang BY, Liu Y, Mehta JL, Hermonat PL: Systemic human Netrin-1 gene delivery by adeno-associated virus type 8 alters leukocyte accumulation and atherogenesis in vivo. Gene Ther 2011, 18:437-444.

42. Goehringer C, Rutschow D, Bauer R, Schinkel S, Weichenhan D, Bekeredjian R, Straub V, Kleinschmidt JA, Katus HA, Muller OJ: Prevention of cardiomyopathy in delta-sarcoglycan knockout mice after systemic transfer of targeted adeno-associated viral vectors. Cardiovasc Res 2009, 82:404410.

43. Bostick B, Yue Y, Long C, Duan D: Prevention of dystrophin-deficient cardiomyopathy in twenty-one-month-old carrier mice by mosaic dystrophin expression or complementary dystrophin/utrophin expression. Circ Res 2008, 102:121-130.

*44. Bostick B, Shin J-H, Yue Y, Duan D: AAV-microdystrophin therapy improves cardiac performance in aged female mdx mice. Mol Ther 2011, 19:1826-1832.

*This study demonstrates systemic AAV-9 delivery can treat severe dystrophic cardiomyopathy in a phenotypic model.

45. Shin JH, Nitahara-Kasahara $\mathrm{Y}$, Hayashita-Kinoh H, Ohshima-Hosoyama S, Kinoshita K, Chiyo T, Okada H, Okada T, Takeda S: Improvement of cardiac fibrosis in dystrophic mice by rAAV9-mediated microdystrophin transduction. Gene Ther 2011, 18:910-919.

46. Bostick B, Shin JH, Yue Y, Wasala NB, Lai Y, Duan D: AAV micro-dystrophin gene therapy alleviates stress-induced cardiac death but not myocardial fibrosis in >21-m-old mdx mice, an end-stage model of Duchenne muscular dystrophy cardiomyopathy. J Mol Cell Cardiol 2012, 53:217-222. 
47. Shin JH, Bostick B, Yue Y, Hajjar R, Duan D: SERCA2a gene transfer improves electrocardiographic performance in aged mdx mice. J Transl Med 2011, 9:132.

48. Spampanato C, De Leonibus E, Dama P, Gargiulo A, Fraldi A, Sorrentino NC, Russo F, Nusco E, Auricchio A, Surace EM, et al.: Efficacy of a combined intracerebral and systemic gene delivery approach for the treatment of a severe lysosomal storage disorder. Mol Ther 2011, 19:860-869.

49. Fu H, Dirosario J, Killedar S, Zaraspe K, McCarty DM: Correction of neurological disease of mucopolysaccharidosis IIIB in adult mice by rAAV9 trans-bloodbrain barrier gene delivery. Mol Ther 2011, 19:1025-1033.

50. Katare R, Caporali A, Zentilin L, Avolio E, Sala-Newby G, Oikawa A, Cesselli D, Beltrami AP, Giacca M, Emanueli C, et al.: Intravenous gene therapy with PIM1 via a cardiotropic viral vector halts the progression of diabetic cardiomyopathy through promotion of prosurvival signaling. Circ Res 2011, 108:1238-1251.

51. Dufour BD, Smith CA, Clark RL, Walker TR, McBride JL: Intrajugular vein delivery of AAV9-RNAi prevents neuropathological changes and weight loss in Huntington's disease mice. Mol Ther 2014, 22:797-810.

52. Dong JY, Fan PD, Frizzell RA: Quantitative analysis of the packaging capacity of recombinant adeno-associated virus. Hum Gene Ther 1996, 7:2101-2112.

53. Dong $B$, Nakai $H$, Xiao W: Characterization of genome integrity for oversized recombinant AAV vector. Mol Ther 2010, 18:87-92.

54. Lai $Y$, Yue $Y$, Duan D: Evidence for the failure of adeno-associated virus serotype 5 to package a viral genome $>$ or $=\mathbf{8 . 2} \mathbf{k b}$. Mol Ther 2010, 18:75-79.

55. Wu Z, Yang H, Colosi P: Effect of genome size on AAV vector packaging. $\mathrm{Mol}$ Ther 2010, 18:80-86.

56. Chamberlain K, Riyad JM, Weber T: Expressing transgenes that exceed the packaging capacity of adeno-associated virus capsids. Hum Gene Ther Methods 2016, 27:1-12.

57. Hirsch ML, Wolf SJ, Samulski RJ: Delivering transgenic DNA exceeding the carrying capacity of AAV vectors. Methods Mol Biol 2016, 1382:21-39.

58. Ghosh A, Duan D: Expending adeno-associated viral vector capacity: a tale of two vectors. Biotechnology and Genetic Engineering Reviews 2007, 24:165177.

59. Lai Y, Yue Y, Liu M, Ghosh A, Engelhardt JF, Chamberlain JS, Duan D: Efficient in vivo gene expression by trans-splicing adeno-associated viral vectors. Nat Biotechnol 2005, 23:1435-1439.

60. Trapani I, Colella P, Sommella A, lodice C, Cesi G, de Simone S, Marrocco E, Rossi $S$, Giunti M, Palfi A, et al.: Effective delivery of large genes to the retina by dual AAV vectors. EMBO Mol Med 2014, 6:194-211.

*61. Ghosh A, Yue Y, Long C, Bostick B, Duan D: Efficient whole-body transduction with trans-splicing adeno-associated viral vectors. Mol Ther 2007, 15:750755.

*This study demonstrates the feasiblity of systemic delivery with the dual AAV vectors. 
62. Ghosh A, Yue Y, Shin J-H, Duan D: Systemic trans-splicing AAV delivery efficiently transduces the heart of adult mdx mouse, a model for Duchenne muscular dystrophy. Hum Gene Ther 2009, 20:1319-1328.

63. Zhang Y, Yue Y, Li L, Hakim CH, Zhang K, Thomas GD, Duan D: Dual AAV therapy ameliorates exercise-induced muscle injury and functional ischemia in murine models of Duchenne muscular dystrophy. Hum $\mathrm{Mol}$ Genet 2013, 22:3720-3729.

64. Odom GL, Gregorevic P, Allen JM, Chamberlain JS: Gene therapy of mdx mice with large truncated dystrophins generated by recombination using rAAV6. Mol Ther 2011, 19:36-45.

65. Lostal W, Bartoli M, Bourg N, Roudaut C, Bentaib A, Miyake K, Guerchet N, Fougerousse $F$, McNeil $P$, Richard I: Efficient recovery of dysferlin deficiency by dual adeno-associated vector-mediated gene transfer. Hum Mol Genet 2010, 19:1897-1907.

*66. Yue Y, Ghosh A, Long C, Bostick B, Smith BF, Kornegay JN, Duan D: A single intravenous injection of adeno-associated virus serotype-9 leads to whole body skeletal muscle transduction in dogs. Mol Ther 2008, 16:1944-1952.

*This is the first study demonstrating efficiency systemic AAV delivery in a large mammalian species.

67. Pan X, Yue Y, Zhang K, Lostal W, Shin JH, Duan D: Long-term robust myocardial transduction of the dog heart from a peripheral vein by adeno-associated virus serotype-8. Hum Gene Ther 2013, 24:584-594.

68. Pan X, Yue Y, Zhang K, Hakim CH, Kodippili K, McDonald T, Duan D: AAV-8 is more efficient than AAV-9 in transducing neonatal dog heart. Hum Gene Ther Methods 2015, 26:54-61.

69. Zhong L, Li B, Mah CS, Govindasamy L, Agbandje-McKenna M, Cooper M, Herzog RW, Zolotukhin I, Warrington KH, Jr., Weigel-Van Aken KA, et al.: Next generation of adeno-associated virus 2 vectors: point mutations in tyrosines lead to high-efficiency transduction at lower doses. Proc Natl Acad Sci U S A 2008, 105:7827-7832.

70. Qiao C, Zhang W, Yuan Z, Shin JH, Li J, Jayandharan GR, Zhong L, Srivastava A, Xiao X, Duan D: AAV6 capsid tyrosine to phenylalanine mutations improve gene transfer to skeletal muscle. Hum Gene Ther 2010, 21:1343-1348.

71. Hakim CH, Yue Y, Shin JH, Williams RR, Zhang K, Smith BF, Duan D: Systemic gene transfer reveals distinctive muscle transduction profile of tyrosine mutant AAV-1, -6, and -9 in neonatal dogs. Mol Ther Methods Clin Dev 2014, 1:14002.

72. Duan D: Duchenne muscular dystrophy gene therapy in the canine model. Hum Gene Ther Clin Dev 2015, 26:57-69.

*73. Kornegay JN, Li J, Bogan JR, Bogan DJ, Chen C, Zheng H, Wang B, Qiao C, Howard JF, Jr., Xiao X: Widespread muscle expression of an AAV9 human mini-dystrophin vector after intravenous injection in neonatal dystrophindeficient dogs. Mol Ther 2010, 18:1501-1508.

*This study suggests that systemic delivery may induce catastrophic inflammatory response in a diseased large mammal. 
74. Hinderer C, Bell P, Louboutin JP, Zhu Y, Yu H, Lin G, Choa R, Gurda BL, Bagel J, O'Donnell $P$, et al.: Neonatal systemic AAV induces tolerance to CNS gene therapy in MPS I dogs and nonhuman primates. Mol Ther 2015, 23:12981307.

75. Mori S, Takeuchi T, Enomoto Y, Kondo K, Sato K, Ono F, Iwata N, Sata T, Kanda T: Biodistribution of a low dose of intravenously administered AAV-2, 10, and 11 vectors to cynomolgus monkeys. Jpn J Infect Dis 2006, 59:285-293.

76. Rodino-Klapac LR, Montgomery CL, Bremer WG, Shontz KM, Malik V, Davis N, Sprinkle S, Campbell KJ, Sahenk Z, Clark KR, et al.: Persistent expression of FLAG-tagged micro dystrophin in nonhuman primates following intramuscular and vascular delivery. Mol Ther 2010, 18:109-117.

77. Toromanoff A, Adjali O, Larcher T, Hill M, Guigand L, Chenuaud P, Deschamps JY, Gauthier O, Blancho G, Vanhove B, et al.: Lack of immunotoxicity after regional intravenous (RI) delivery of rAAV to nonhuman primate skeletal muscle. Mol Ther 2010, 18:151-160.

78. Toromanoff A, Cherel Y, Guilbaud M, Penaud-Budloo M, Snyder RO, Haskins ME, Deschamps JY, Guigand L, Podevin G, Arruda VR, et al.: Safety and efficacy of regional intravenous (r.i.) versus intramuscular (i.m.) delivery of rAAV1 and rAAV8 to nonhuman primate skeletal muscle. Mol Ther 2008, 16:1291-1299.

79. Qiao C, Li J, Zheng H, Bogan J, Yuan Z, Zhang C, Bogan D, Kornegay J, Xiao X:

Hydrodynamic limb vein injection of AAV8 canine myostatin propeptide gene in normal dogs enhances muscle growth. Hum Gene Ther 2009, 20:110.

80. Vulin A, Barthelemy I, Goyenvalle A, Thibaud JL, Beley C, Griffith G, Benchaouir R, le Hir M, Unterfinger $\mathrm{Y}$, Lorain $\mathrm{S}$, et al.: Muscle function recovery in golden retriever muscular dystrophy after AAV1-U7 exon skipping. Mol Ther 2012, 20:2120-2133.

81. Le Guiner C, Montus M, Servais L, Cherel Y, Francois V, Thibaud JL, Wary C, Matot $B$, Larcher T, Guigand L, et al.: Forelimb treatment in a large cohort of dystrophic dogs supports delivery of a recombinant AAV for exon skipping in Duchenne patients. Mol Ther 2014, 22:1923-1935.

*82. Childers MK, Joubert R, Poulard K, Moal C, Grange RW, Doering JA, Lawlor MW, Rider BE, Jamet T, Daniele N, et al.: Gene therapy prolongs survival and restores function in murine and canine models of myotubular myopathy. Sci Transl Med 2014, 6:220ra210.

*This study suggests that isolated limb perfusion can result in bodywide improvement if the therapeutic product is an enzyme. The authors also showed that intravenous delivery of AAV-8 did not induce any immune response in the canine model of myotubular myopathy.

**83. Yue Y, Pan X, Hakim CH, Kodippili K, Zhang K, Shin JH, Yang HT, McDonald T, Duan D: Safe and bodywide muscle transduction in young adult Duchenne muscular dystrophy dogs with adeno-associated virus. Hum Mol Genet 2015, 24:5880-5890.

**This is the first study demonstraing successful systemic AAV delivery in young adult subjects in a large animal model of human diseases. This study sets the 
foundation for conducting systemic AAV therapy in boys afflicted by Duchenne muscular dystrophy.

84. Hakim CH, Pan X, Kodippili K, Blessa T, Yang HT, Yao G, Leach S, Emter C, Yue $\mathrm{Y}$, Zhang $\mathrm{K}$, et al.: Intravenous delivery of a novel micro-dystrophin vector prevented muscle deterioration in young adult canine Duchenne muscular dystrophy dogs. Mol Ther 2016, 24:S198-199.

**85. Mendell JR, Al-Zaidy S, Shell R, Arnold WD, Rodino-Klapac L, Kissel JT, Prior TW, Miranda C, Lowes L, Alfano L, et al.: Gene therapy for spinal muscular atrophy type 1 shows potential to improve survival and motor functional outcomes. Mol Ther 2016, 24:S190.

**In this meeting report, Dr. Mendell presented results of the first-in-human study on systemic AAV gene therapy in severelly affected newborn spinal muscular dystrophy patients. A total of 15 patients have been treated with an AAV-9 vector at the dose of $6.7 \times 10^{13}$ to $2 \times 10^{14}$ for 4 months to 2 years. The results of this ongoing study suggest that systemic AAV gene therapy is safe and may dramatically change the disease course. This study opens the door for systemic AAV gene therapy for other diseases in human patients.

86. Valori CF, Ning K, Wyles M, Mead RJ, Grierson AJ, Shaw PJ, Azzouz M: Systemic delivery of ScAAV9 expressing SMN prolongs survival in a model of spinal muscular atrophy. Sci Transl Med 2010, 2:35ra42.

87. Bevan AK, Hutchinson KR, Foust KD, Braun L, McGovern VL, Schmelzer L, Ward JG, Petruska JC, Lucchesi PA, Burghes AH, et al.: Early heart failure in the SMNDelta7 model of spinal muscular atrophy and correction by postnatal ScAAV9-SMN delivery. Hum Mol Genet 2010, 19:3895-3905.

88. Foust KD, Wang X, McGovern VL, Braun L, Bevan AK, Haidet AM, Le TT, Morales $\mathrm{PR}$, Rich MM, Burghes $\mathrm{AH}$, et al.: Rescue of the spinal muscular atrophy phenotype in a mouse model by early postnatal delivery of SMN. Nat Biotechnol 2010, 28:271-274.

89. Dominguez E, Marais T, Chatauret N, Benkhelifa-Ziyyat S, Duque S, Ravassard P, Carcenac R, Astord S, Pereira de Moura A, Voit T, et al.: Intravenous scAAV9 delivery of a codon-optimized SMN1 sequence rescues SMA mice. Hum Mol Genet 2011, 20:681-693.

90. Ding W, Zhang L, Yan Z, Engelhardt JF: Intracellular trafficking of adenoassociated viral vectors. Gene Ther 2005, 12:873-880.

91. Nonnenmacher M, Weber T: Intracellular transport of recombinant adenoassociated virus vectors. Gene Ther 2012, 19:649-658.

92. Denard J, Beley C, Kotin R, Lai-Kuen R, Blot S, Leh H, Asokan A, Samulski RJ, Moullier $\mathrm{P}$, Voit $\mathrm{T}$, et al.: Human galectin 3 binding protein interacts with recombinant adeno-associated virus type 6. J Virol 2012, 86:6620-6631.

93. Denard J, Marolleau B, Jenny C, Rao TN, Fehling HJ, Voit T, Svinartchouk F: Creactive protein (CRP) is essential for efficient systemic transduction of recombinant adeno-associated virus vector 1 (rAAV-1) and rAAV-6 in mice. J Virol 2013, 87:10784-10791. 
94. Kotchey NM, Adachi K, Zahid M, Inagaki K, Charan R, Parker RS, Nakai H: A potential role of distinctively delayed blood clearance of recombinant adeno-associated virus serotype 9 in robust cardiac transduction. Mol Ther 2011, 19:1079-1089.

95. Shen S, Bryant KD, Sun J, Brown SM, Troupes A, Pulicherla N, Asokan A: Glycan binding avidity determines the systemic fate of adeno-associated virus type 9. J Virol 2012, 86:10408-10417.

*96. Asokan A, Conway JC, Phillips JL, Li C, Hegge J, Sinnott R, Yadav S, DiPrimio N, $\mathrm{Nam} \mathrm{HJ}$, Agbandje-McKenna $\mathrm{M}$, et al.: Reengineering a receptor footprint of adeno-associated virus enables selective and systemic gene transfer to muscle. Nat Biotechnol 2010, 28:79-82.

*This study provides the proof-of-principle to engineer AAV capsid for improved systemic delivery.

97. Gray SJ, Matagne V, Bachaboina L, Yadav S, Ojeda SR, Samulski RJ: Preclinical differences of intravascular AAV9 delivery to neurons and glia: a comparative study of adult mice and nonhuman primates. Mol Ther 2011, 19:1058-1069.

98. Tuma P, Hubbard AL: Transcytosis: crossing cellular barriers. Physiol Rev 2003, 83:871-932.

99. Di Pasquale G, Ostedgaard L, Vermeer D, Swaim WD, Karp P, Chiorini JA: Bovine AAV transcytosis inhibition by tannic acid results in functional expression of CFTR in vitro and altered biodistribution in vivo. Gene Ther 2012, 19:576581.

*100. Di Pasquale G, Chiorini JA: AAV transcytosis through barrier epithelia and endothelium. Mol Ther 2006, 13:506-516.

*This study provides in vitro evidence of AAV transcytosis.

101. He B, Yuan Z, Qiao C, Madden V, Thakker D, Li J, Xiao X: Transcytosis of AAV8 and AAV9 across endothelial Barrier. Mol Ther 2009, 17:S175.

102. Byrne LC, Lin YJ, Lee T, Schaffer DV, Flannery JG: The expression pattern of systemically injected AAV9 in the developing mouse retina is determined by age. Mol Ther 2015, 23:290-296.

103. Cheng JP, Nichols BJ: Caveolae: one function or many? Trends Cell Biol 2016, 26:177-189.

104. Foust KD, Nurre E, Montgomery CL, Hernandez A, Chan CM, Kaspar BK: Intravascular AAV9 preferentially targets neonatal neurons and adult astrocytes. Nat Biotechnol 2009, 27:59-65.

105. Calcedo R, Vandenberghe LH, Gao G, Lin J, Wilson JM: Worldwide epidemiology of neutralizing antibodies to adeno-associated viruses. $J$ Infect Dis 2009, 199:381-390.

106. Boutin S, Monteilhet V, Veron P, Leborgne C, Benveniste O, Montus MF, Masurier $C$ : Prevalence of serum IgG and neutralizing factors against adenoassociated virus (AAV) types 1, 2, 5, 6, 8, and 9 in the healthy population: implications for gene therapy using AAV vectors. Hum Gene Ther 2010, 21:704-712. 
107. Van Vliet KM, Blouin V, Brument N, Agbandje-McKenna M, Snyder RO: The role of the adeno-associated virus capsid in gene transfer. Methods $\mathrm{Mol} B i o l$ 2008, 437:51-91.

*108. Drouin LM, Agbandje-McKenna M: Adeno-associated virus structural biology as a tool in vector development. Future Virol 2013, 8:1183-1199.

${ }^{*}$ This is an excellent review article on AAV capsid structure.

109. Agbandje-McKenna M, Kleinschmidt J: AAV capsid structure and cell interactions. Methods Mol Biol 2011, 807:47-92.

110. Santiago-Ortiz J, Ojala DS, Westesson O, Weinstein JR, Wong SY, Steinsapir A, Kumar S, Holmes I, Schaffer DV: AAV ancestral reconstruction library enables selection of broadly infectious viral variants. Gene Ther 2015, 22:934-946.

111. Zinn E, Pacouret S, Khaychuk V, Turunen HT, Carvalho LS, Andres-Mateos E, Shah S, Shelke R, Maurer AC, Plovie E, et al.: In Silico reconstruction of the viral evolutionary lineage yields a potent gene therapy vector. Cell Rep 2015, 12:1056-1068.

*112. Kotterman MA, Schaffer DV: Engineering adeno-associated viruses for clinical gene therapy. Nat Rev Genet 2014, 15:445-451.

*This is a comprehensive review on the current status of AAV capsid engineering and clinical application of synthetic AAV variants.

113. Nance ME, Duan D: Perspective on adeno-associated virus (AAV) capsid modification for Duchenne muscular dystrophy gene therapy. Hum Gene Ther 2015, In-press.

114. Ling C, Lu Y, Kelsi JK, Jayandharan GR, Li B, Ma W, Cheng B, Gee SW, McGoogan KE, Govindasamy L, et al.: Human hepatocyte growth factor receptor is a cellular co-receptor for AAV3. Hum Gene Ther 2010.

115. Li S, Ling C, Zhong L, Li M, Su Q, He R, Tang Q, Greiner DL, Shultz LD, Brehm $M A$, et al.: Efficient and targeted transduction of nonhuman primate liver with systemically delivered optimized AAV3B vectors. Mol Ther 2015, 23:1867-1876.

116. Wang L, Bell P, Somanathan S, Wang Q, He Z, Yu H, McMenamin D, Goode T, Calcedo R, Wilson JM: Comparative study of liver gene transfer with AAV vectors based on natural and engineered AAV capsids. Mol Ther 2015, 23:1877-1887.

117. Shen S, Troupes AN, Pulicherla N, Asokan A: Multiple roles for sialylated glycans in determining the cardiopulmonary tropism of adeno-associated virus 4. J Virol 2013, 87:13206-13213.

118. Yang B, Li S, Wang H, Guo Y, Gessler DJ, Cao C, Su Q, Kramer J, Zhong L, Ahmed SS, et al.: Global CNS transduction of adult mice by intravenously delivered rAAVrh.8 and rAAVrh.10 and nonhuman primates by rAAVrh.10. Mol Ther 2014, 22:1299-1309.

119. Louis Jeune V, Joergensen JA, Hajjar RJ, Weber T: Pre-existing anti-adenoassociated virus antibodies as a challenge in AAV gene therapy. Hum Gene Ther Methods 2013, 24:59-67. 
120. Mingozzi F, Chen Y, Edmonson SC, Zhou S, Thurlings RM, Tak PP, High KA, Vervoordeldonk $\mathrm{MJ}$ : Prevalence and pharmacological modulation of humoral immunity to AAV vectors in gene transfer to synovial tissue. Gene Ther 2013, 20:417-424.

121. Mingozzi F, Chen Y, Murphy SL, Edmonson SC, Tai A, Price SD, Metzger ME, Zhou S, Wright JF, Donahue RE, et al.: Pharmacological modulation of humoral immunity in a nonhuman primate model of AAV gene transfer for hemophilia B. Mol Ther 2012, 20:1410-1416.

122. Monteilhet V, Saheb S, Boutin S, Leborgne C, Veron P, Montus MF, Moullier P, Benveniste $O$, Masurier C: A 10 patient case report on the impact of plasmapheresis upon neutralizing factors against adeno-associated virus (AAV) types 1, 2, 6, and 8. Mol Ther 2011, 19:2084-2091.

123. Tseng YS, Agbandje-McKenna M: Mapping the AAV capsid host antibody response toward the development of second generation gene delivery vectors. Front Immunol 2014, 5:9.

124. Lochrie MA, Tatsuno GP, Christie B, McDonnell JW, Zhou S, Surosky R, Pierce GF, Colosi P: Mutations on the external surfaces of adeno-associated virus type 2 capsids that affect transduction and neutralization. $J$ Virol 2006, 80:821-834.

125. Maersch S, Huber A, Buning H, Hallek M, Perabo L: Optimization of stealth adeno-associated virus vectors by randomization of immunogenic epitopes. Virology 2010, 397:167-175.

126. Bartel M, Schaffer $D$, Buning $H$ : Enhancing the clinical potential of AAV vectors by capsid engineering to evade pre-existing immunity. Front Microbiol 2011, 2:204.

*127. Maheshri N, Koerber JT, Kaspar BK, Schaffer DV: Directed evolution of adenoassociated virus yields enhanced gene delivery vectors. Nat Biotechnol 2006, 24:198-204.

*This paper describes the first application of directed evolution to generate novel AAV capsids. This library-based approach allows investigators to obtain functionally superior AAV mutants without prior knowledge on the capsid structure.

128. Grimm D, Lee JS, Wang L, Desai T, Akache B, Storm TA, Kay MA: In vitro and in vivo gene therapy vector evolution via multispecies interbreeding and retargeting of adeno-associated viruses. $J$ Virol 2008, 82:5887-5911.

129. Li C, Wu S, Albright B, Hirsch M, Li W, Tseng YS, Agbandje-McKenna M, McPhee S, Asokan A, Samulski RJ: Development of patient-specific AAV vectors after neutralizing antibody selection for enhanced muscle gene transfer. $\mathrm{Mol}$ Ther 2016, 24:53-65.

130. Adachi K, Enoki T, Kawano Y, Veraz M, Nakai H: Drawing a high-resolution functional map of adeno-associated virus capsid by massively parallel sequencing. Nat Commun 2014, 5:3075.

131. Pulicherla N, Shen S, Yadav S, Debbink K, Govindasamy L, Agbandje-McKenna M, Asokan A: Engineering liver-detargeted AAV9 vectors for cardiac and musculoskeletal gene transfer. Mol Ther 2011, 19:1070-1078. 
132. Shen S, Horowitz ED, Troupes AN, Brown SM, Pulicherla N, Samulski RJ, Agbandje-McKenna M, Asokan A: Engraftment of a galactose receptor footprint onto adeno-associated viral capsids improves transduction efficiency. J Biol Chem 2013, 288:28814-28823.

*133. Lisowski L, Dane AP, Chu K, Zhang Y, Cunningham SC, Wilson EM, Nygaard S, Grompe M, Alexander IE, Kay MA: Selection and evaluation of clinically relevant AAV variants in a xenograft liver model. Nature 2014, 506:382-386.

*This study decribes a unique in vivo evolution approach in human tissue xenograft. The resulting AAV variants hold great promise for human application.

134. Yang L, Jiang J, Drouin LM, Agbandje-McKenna M, Chen C, Qiao C, Pu D, Hu X, Wang DZ, Li J, et al.: A myocardium tropic adeno-associated virus (AAV) evolved by DNA shuffling and in vivo selection. Proc Natl Acad Sci U S A 2009, 106:3946-3951.

135. Choudhury SR, Harris AF, Cabral DJ, Keeler AM, Sapp E, Ferreira JS, GrayEdwards HL, Johnson JA, Johnson AK, Su Q, et al.: Widespread central nervous system gene transfer and silencing after systemic delivery of novel AAV-AS vector. Mol Ther 2016, 24:726-735.

136. Huang LY, Halder S, Agbandje-McKenna M: Parvovirus glycan interactions. Curr Opin Virol 2014, 7:108-118.

137. Murlidharan G, Corriher T, Ghashghaei HT, Asokan A: Unique glycan signatures regulate adeno-associated virus tropism in the developing brain. $J$ Virol 2015, 89:3976-3987.

*138. Pillay S, Meyer NL, Puschnik AS, Davulcu O, Diep J, Ishikawa Y, Jae LT, Wosen JE, Nagamine CM, Chapman MS, et al.: An essential receptor for adenoassociated virus infection. Nature 2016, 530:108-112.

*This paper describes the identification of a poorly characterized transmembrane protein KIAA0319L as a ubiqutous AAV receptor for multiple serotypes.

139. Nelson CE, Hakim CH, Ousterout DG, Thakore PI, Moreb EA, Rivera RM, Madhavan S, Pan X, Ran FA, Yan WX, et al.: In vivo genome editing improves muscle function in a mouse model of Duchenne muscular dystrophy. Science 2016, 351:403-407.

140. Rayaprolu V, Kruse S, Kant R, Venkatakrishnan B, Movahed N, Brooke D, Lins B, Bennett A, Potter T, McKenna R, et al.: Comparative analysis of adenoassociated virus capsid stability and dynamics. J Virol 2013, 87:13150-13160.

141. Vandenberghe LH, Wang L, Somanathan S, Zhi Y, Figueredo J, Calcedo R, Sanmiguel J, Desai RA, Chen CS, Johnston J, et al.: Heparin binding directs activation of T cells against adeno-associated virus serotype 2 capsid. Nat Med 2006, 12:967-971.

142. Lu Y, Song S: Distinct immune responses to transgene products from rAAV1 and rAAV8 vectors. Proc Natl Acad Sci U S A 2009, 106:17158-17162.

143. Wang L, Figueredo J, Calcedo R, Lin J, Wilson JM: Cross-presentation of adeno-associated virus serotype 2 capsids activates cytotoxic $T$ cells but does not render hepatocytes effective cytolytic targets. Hum Gene Ther 2007, 18:185-194. 
144. Ohshima S, Shin JH, Yuasa K, Nishiyama A, Kira J, Okada T, Takeda S: Transduction efficiency and immune response associated with the administration of AAV8 vector into dog skeletal muscle. Mol Ther 2009, 17:7380.

145. Mays LE, Wang L, Lin J, Bell P, Crawford A, Wherry EJ, Wilson JM: AAV8 induces tolerance in murine muscle as a result of poor APC transduction, $T$ cell exhaustion and minimal $\mathrm{MHCl}$ upregulation on target cells. Mol Ther 2014, 22:28-41.

146. Koo T, Okada T, Athanasopoulos T, Foster H, Takeda S, Dickson G: Long-term functional adeno-associated virus-microdystrophin expression in the dystrophic CXMDj dog. J Gene Med 2011, 13:497-506.

147. Qiao C, Li J, Zheng H, Bogan J, Yuan Z, Zhang C, Bogan D, Kornegay J, Xiao X: Hydrodynamic limb vein injection of AAV8 canine myostatin propeptide gene in normal dogs enhances muscle growth. Hum Gene Ther 2009, 20:1-10. 
Table 1. Comparison of AAV-2 with $\mathrm{AAV}-1,6,7,8$ and 9 for systemic delivery

\begin{tabular}{|c|c|c|c|c|c|c|c|}
\hline & AAV-1 & AAV-2 & AAV-6 & AAV-7 & AAV-8 & AAV-9 & References \\
\hline In vitro capsid stability & Moderate & Low & $?$ & $?$ & Moderate & $?$ & 140 \\
\hline Blood clearance & Fast & Fast & Fast & Fast & Fast & Slow & 31,94 \\
\hline Transcytosis & $?$ & Poor & Poor & $?$ & High & High & 99-101 \\
\hline $\begin{array}{l}\text { Direct muscle } \\
\text { transduction efficiency }\end{array}$ & High & Moderate & Very high & High & Moderate & High Very high & 23,129 \\
\hline $\begin{array}{l}\text { Systemic transduction } \\
\text { efficiency }\end{array}$ & High & Low & High & High & High Very high & Very high & $26,30-32$ \\
\hline Unique features & & $\begin{array}{l}\text { Very efficient in } \\
\text { cultured cells }\end{array}$ & & & Low immunity $^{\mathrm{a}}$ & $\begin{array}{l}\text { Cardiotropic in } \\
\text { rodents }^{\mathrm{b}} \text { : Cross } \mathrm{BBB}^{\mathrm{c}}\end{array}$ & \\
\hline
\end{tabular}

a, See references 40, 82, and 141-147.

b, See references 27-29 and 30-32.

c, See references 85-89. BBB, blood-brain-barrier 


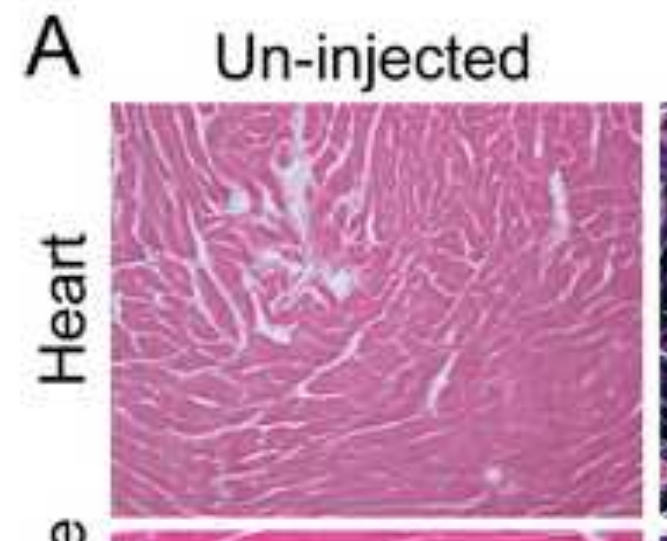

\section{AAV-9 injected}
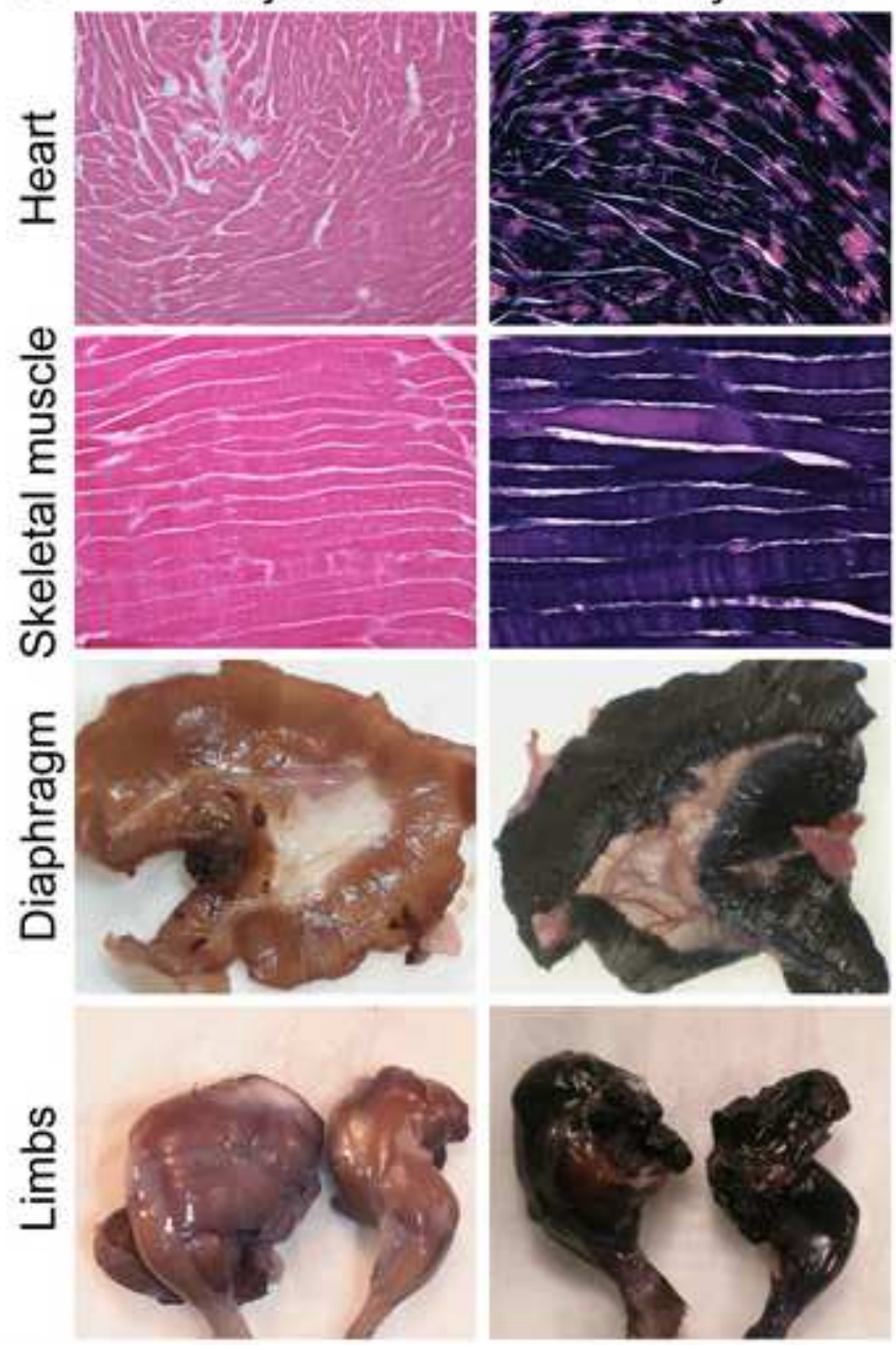

B

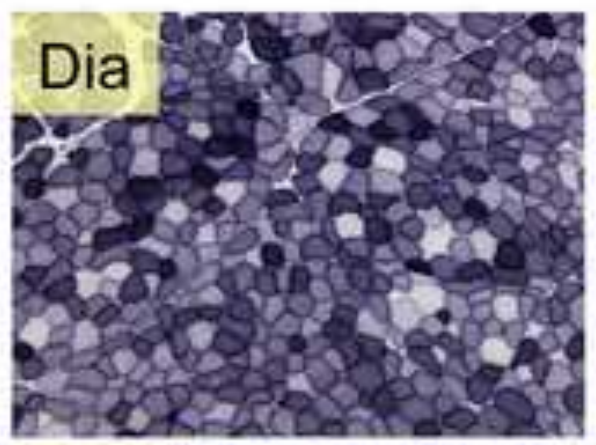

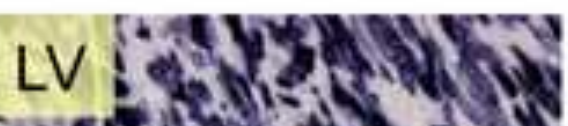
wanks an mons - ins misomet 2mindes.

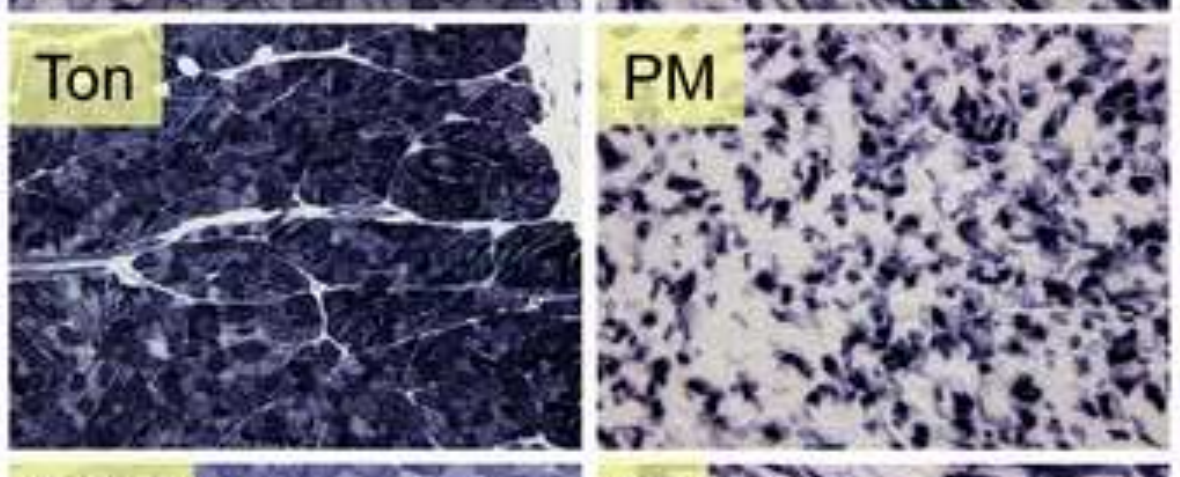
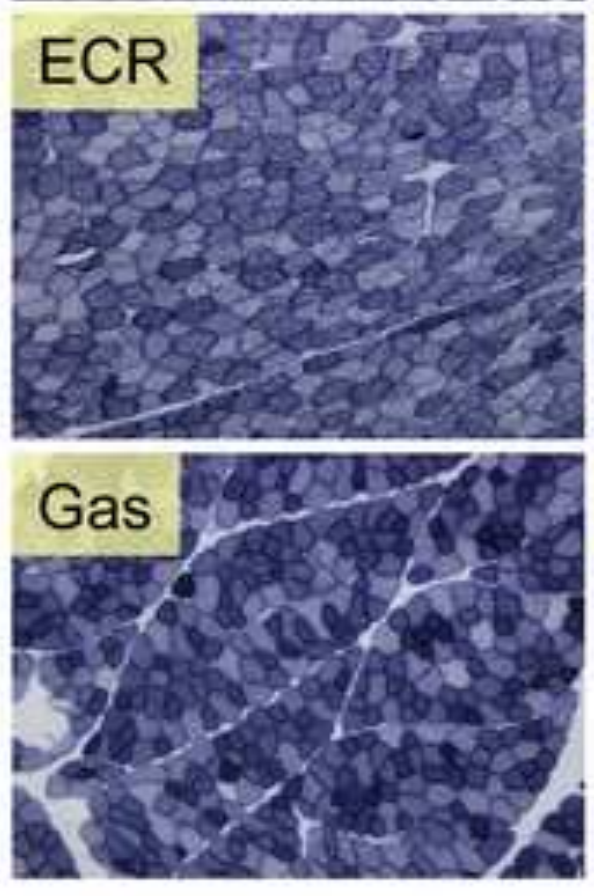

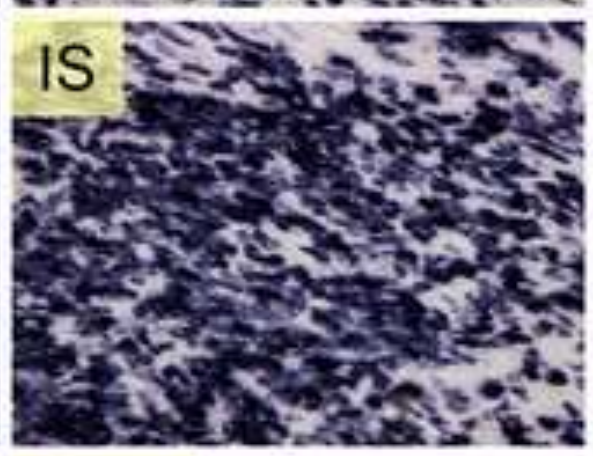

Liver 

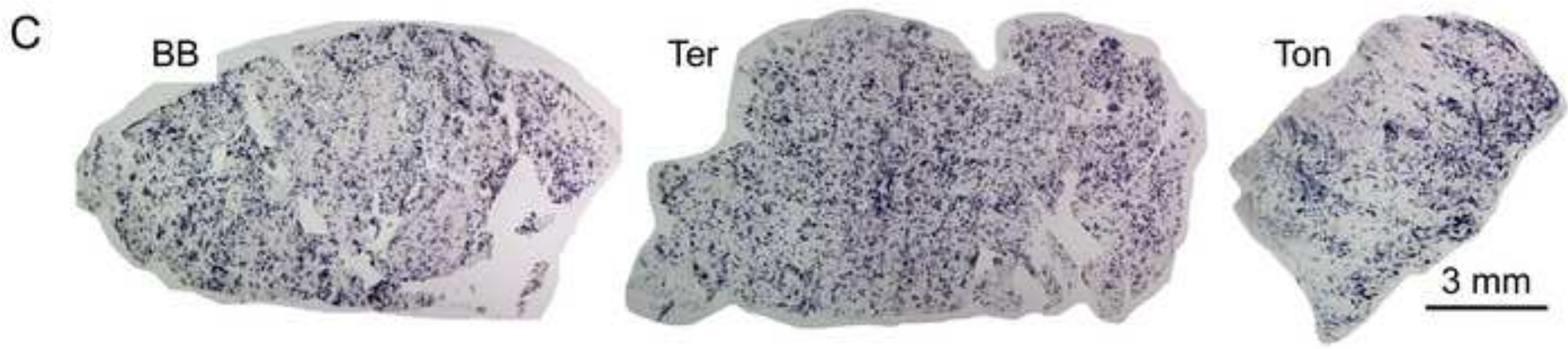

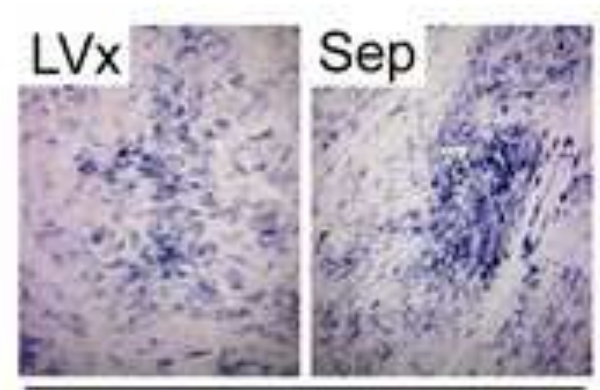

Heart

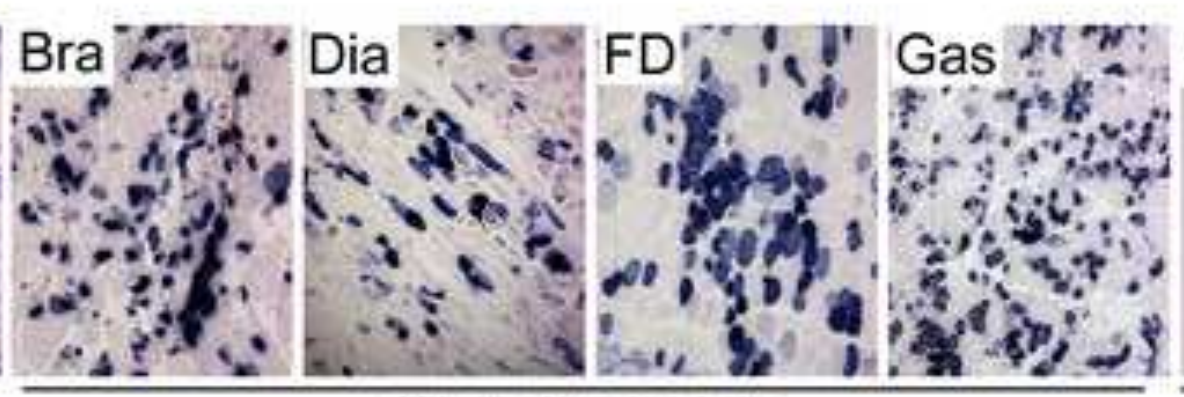

Skeletal muscle
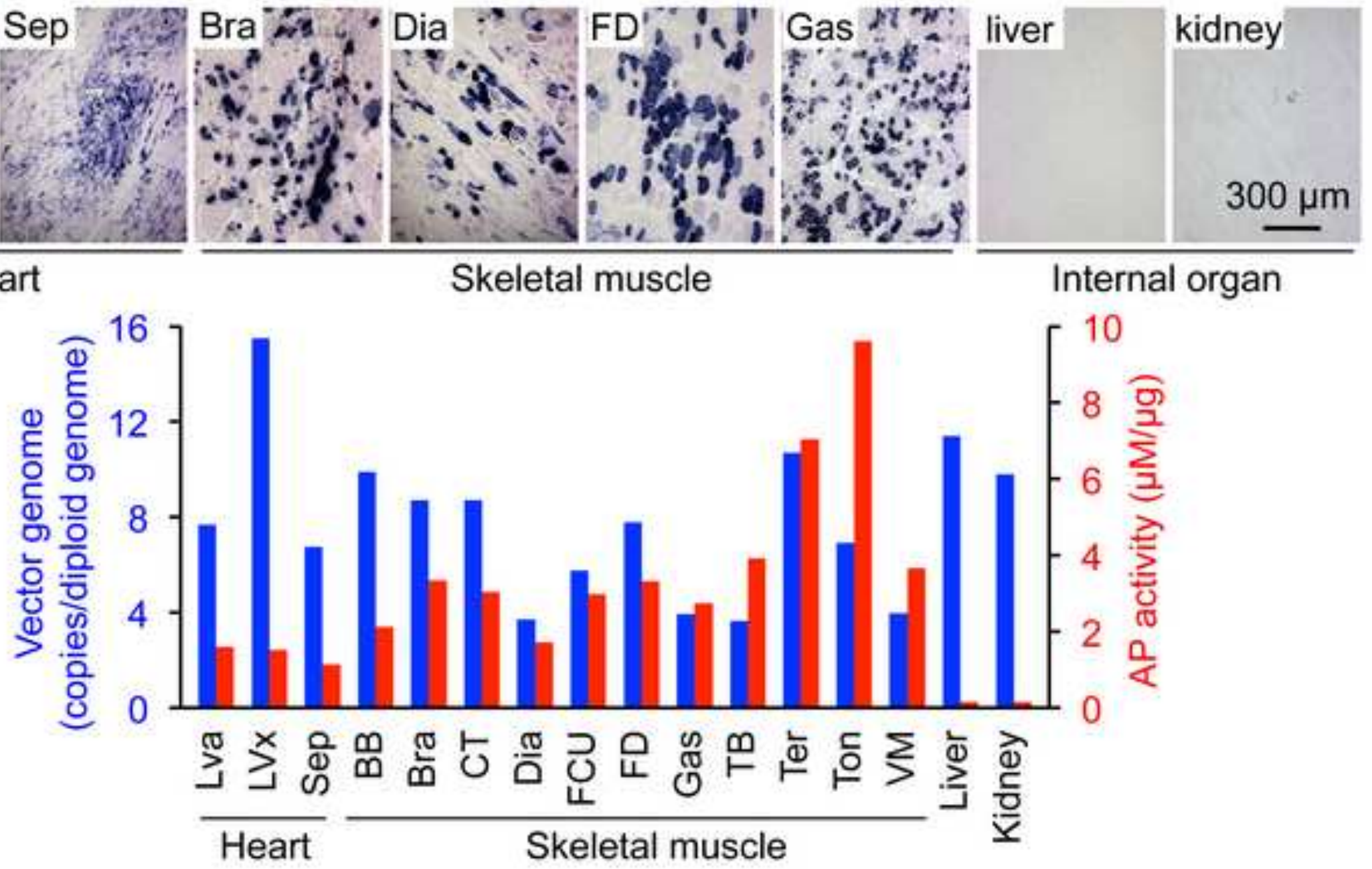
(1) Blood clearance

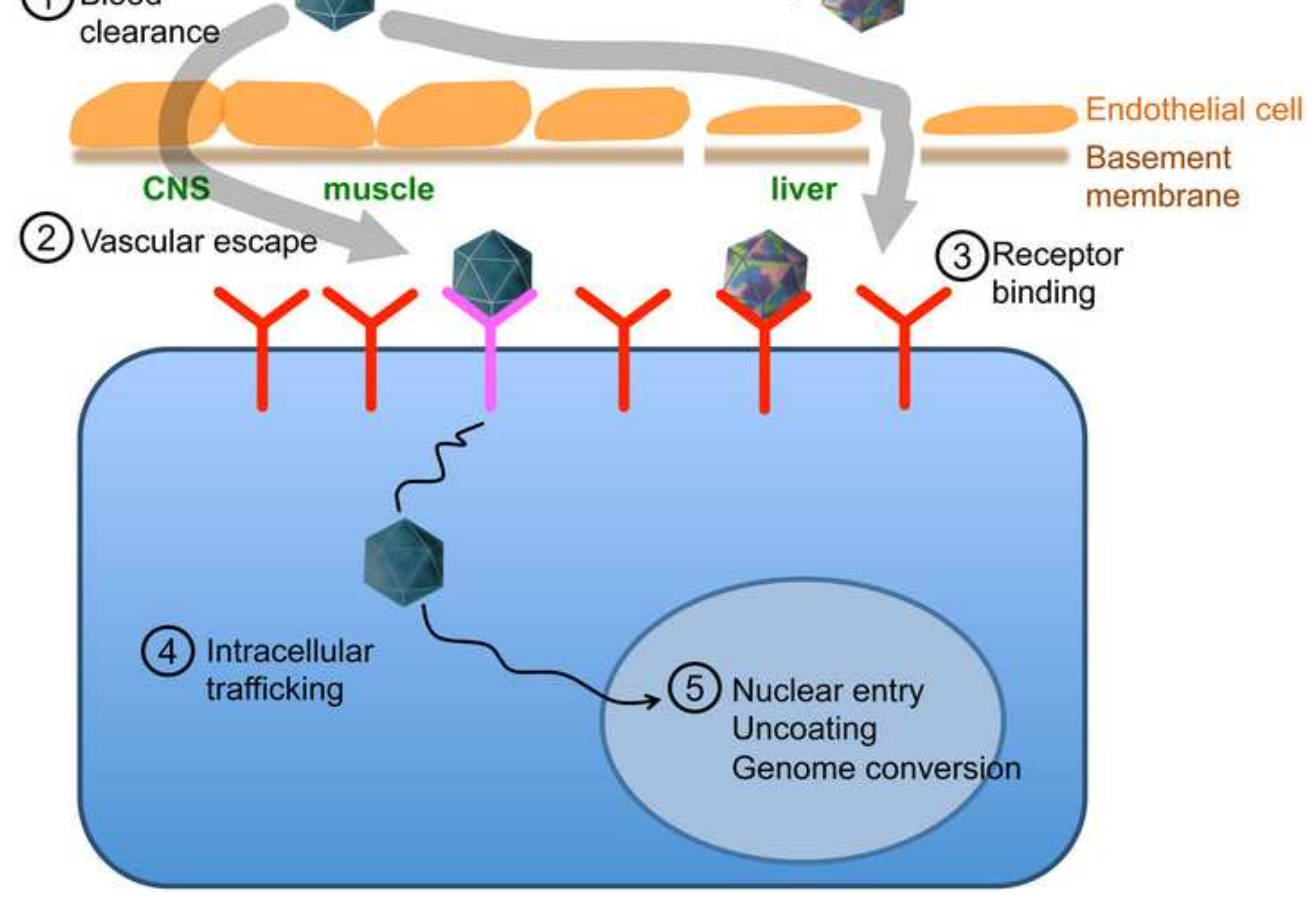

(2) Vascular escape
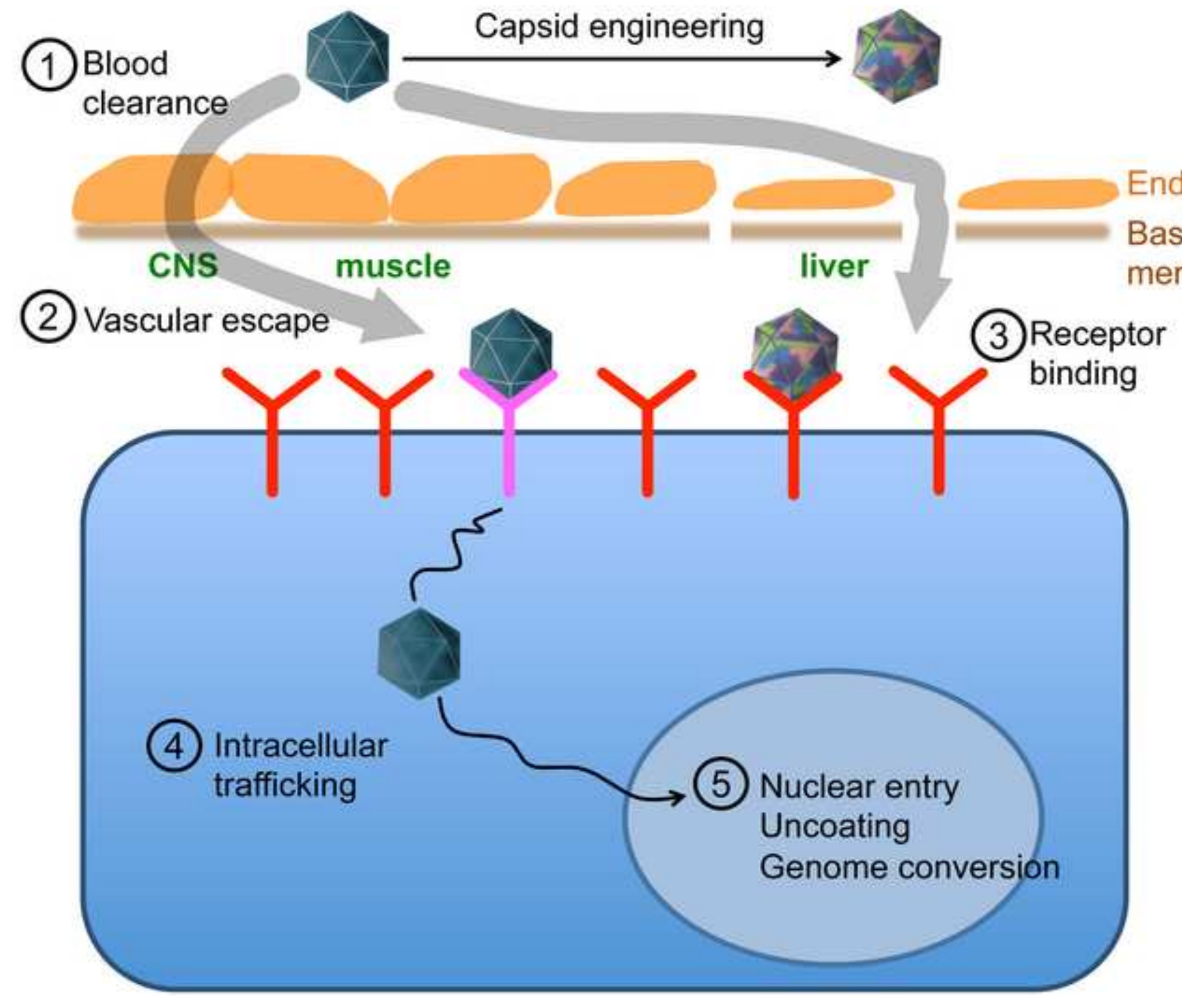

(3) Receptor
binding membrane 